\title{
STUDI KELIMPAHAN GASTROPODA (Lambis spp.) PADA DAERAH MAKROALGA DI PULAU PRAMUKA, KEPULAUAN SERIBU
}

\author{
Sahila Rizkya, Siti Rudiyanti, Max Rudolf Muskananfola*) \\ Jurusan Perikanan, Fakultas Perikanan dan Ilmu Kelautan, Universitas Diponegoro \\ Jl. Prof. H. Soedharto, SH, Tembalang Semarang. 50275 Telp/Fax (024) 7474698
}

\begin{abstract}
Abstrak
Penelitian ini dilaksanakan pada bulan April 2012 di Pulau Pramuka, Kepulauan Seribu, DKI Jakarta. Teknik pengambilan sampel menggunakan metode purposive sampling artinya sesuai dengan namanya, sampel diambil dengan maksud atau tujuan tertentu. Kuadran transek berukuran $1 \times 1 \mathrm{~m}$ diletakkan jarak 10 meter dari satu plot ke plot berikutnya dengan arah tegak lurus garis pantai sampai ke tubir atau daerah yang pertumbuhan makroalganya sangat jarang, kemudian dengan menggunakan line transek sepanjang 100 meter ditarik tegak lurus dari garis pantai ke arah tubir. Hasil penelitian yang didapatkan adalah kelimpahan Lambis yang didapatkan pada Pulau Pramuka selama penelitian seluruhnya ada 21 individu, dengan jumlah total pada Stasiun 1 yaitu 11 individu, pada Stasiun 2 dengan jumlah 2 individu dan Stasiun yang ke 3 dengan jumlah 8 individu. Spesies Lambis spp. yang ditemukan saat penelitian yaitu Lambis crocata, Lambis lambis, Lambis scorpius, dan Lambis chiragra dengan komposisi Lambis crocata 52 \%, Lambis lambis $29 \%$, Lambis scorpius $14 \%$ dan yang paling rendah yaitu Lambis chiragra dengan $5 \%$. Jenis-jenis makroalga yang ditemukan adalah spesies Sargassum sp, Halimeda sp, Padina sp, Caulerpa sp dan Euchema sp.
\end{abstract}

Kata kunci : Gastropoda (Lambis spp.), Makroalga, Pulau Pramuka

\begin{abstract}
The study was conducted on April 2012 at Pramuka Island, Seribu Island, Jakarta. The sampling technique used purposive sampling method means that as the name suggests, the samples were taken with the intent or purpose. Transect quadrant $1 \times 1 \mathrm{~m}$ placed a distance of 10 meters from one plot to the next plot in the direction perpendicular to the shoreline or the edge of a growth area macroalgae very rarely, and then using the line transect along the 100 meter perpendicular drawn from the shoreline to the edge. The results obtained are found in abundance Lambis the Pramuka Island during the study a total of 21 individuals, with the total at Station 1 is 11 individuals, at Station 2 with 2 individuals and the number of stations 3 were 8 individuals. Species of Lambis spp. found during the study are Lambis crocata, Lambis lambis, Lambis scorpius, and Lambis chiragra with the composition Lambis crocata 52\%, Lambis lambis 29\%, Lambis scorpius $14 \%$ and the lowest is Lambis chiragra by 5\%. The species of macroalgae found are Sargassum sp, Halimeda sp, Padina sp, Caulerpa sp and Euchema sp.
\end{abstract}

Keywords : Gastropods (Lambis spp.), Macroalgae, Pramuka Island

\section{Pendahuluan}

Gastropoda adalah salah satu komponen dalam ekosistem laut dengan keanekaragaman spesies yang tinggi dan menyebar luas di berbagai habitat laut. Kelompok hewan bertubuh lunak ini dapat dijumpai mulai dari daerah pinggiran pantai hingga laut dalam. Gastropoda banyak menempati daerah terumbu karang, sebagian membenamkan diri dalam sedimen, beberapa dapat dijumpai menempel pada tumbuhan laut seperti mangrove, lamun dan alga (Kasenda, 2012). Sebagaimana halnya gastropoda, makroalga juga merupakan salah satu komponen dalam ekosistem laut. Makroalga merupakan tumbuhan laut yang struktur tubuhnya tak sempurna dan banyak ditemukan di daerah pantai. Makroalga atau seaweed dibedakan dengan mikroalga. Makroalga ukurannya lebih besar, dapat dilihat langsung dengan mata tanpa alat bantu dan menancap atau melekat pada substrat (Kasenda, 2012). Pentingnya peran makroalga sebagai sumber makanan bagi hewan herbivor termasuk gastropoda. Dijelaskan juga bahwa wilayah yang ditumbuhi banyak alga berperan sebagai tempat berlindung invertebrata muda. Ketersediaan makanan dan ruang dapat menjadi penyebab utama terdistribusinya gastropoda pada makroalga. Sebagaimana yang diungkapkan bahwa suatu organisme memilih dan menempati suatu habitat yang aman dari pemangsa dan tersedia makanan yang cukup untuk keberlangsungan hidupnya (Kasenda, 2012).

\footnotetext{
${ }^{*}$ Penulis Penanggung Jawab
} 


\section{Materi dan Metode Penelitian}

A. Materi Penelitian

Materi yang digunakan pada penelitian ini adalah Gastropoda (Lambis spp.) yang hidup di makroalga.

\section{B. Metode Penelitian dan Pengambilan Sampel}

Metode penelitian yang digunakan adalah metode observasi langsung, dimana metode ini bersifat studi kasus (case study) yang menggambarkan secara sistematis, faktual dan akurat mengenai fakta-fakta, sifat-sifat, hubungan antara fenomena, atau peristiwa yang diselidiki pada masa sekarang (Gulo, 2005). Penentuan lokasi stasiun berdasarkan karakteristik substrat dan mewakili setiap bagian titik dalam Pulau Pramuka dimana terbagi menjadi tiga titik atau stasiun yaitu titik (stasiun) utara, timur dan selatan.

Teknik pengambilan sampel menggunakan metode purposive sampling artinya sesuai dengan namanya, sampel diambil dengan maksud atau tujuan tertentu. Metode kuadran transek berukuran 1 x $1 \mathrm{~m}$ yang dilakukan pada saat air surut. Kuadran diletakkan pada jarak 10 meter dari satu plot ke plot berikutnya dengan arah tegak lurus garis pantai sampai ke tubir atau daerah yang pertumbuhan makroalganya sangat jarang, kemudian dengan menggunakan line transek sepanjang 100 meter ditarik tegak lurus dari garis pantai ke arah tubir. Identifikasi gastropoda (Lambis spp.) dilakukan dengan cara pengamatan ciri-ciri fisik Lambis berdasarkan warna, jumlah jari-jari, panjang dan lebar cangkang, kemudian dibandingkan dengan referensi menurut buku yang dikembangkan oleh Departemen Kehutanan (2005) dan Kastoro (1982).

\section{Analisis Data}

\section{Kelimpahan Gastropoda (Lambis spp.)}

Kelimpahan Gastropoda (Lambis spp.) merupakan gambaran banyaknya jenis Gastropoda (Lambis spp.) yang ditemukan pada setiap stasiun/titik sampel. Untuk mengetahui kelimpahan dan kelimpahan relatif digunakan formula menurut Krebs (1985) sebagai berikut:

Kelimpahan relative $(\%)=\frac{\text { jumlah kelimpahan individu species }}{\text { total jumlah kelimpahan seluruh species }} \times 100 \%$

\section{Keanekaragaman, Keseragaman dan Dominansi Gastropoda (Lambis spp.)}

Keanekaragaman menunjukkan keberagaman jenis dan merupakan ciri khas struktur komunitas. Keanekaragaman ditentukan berdasarkan indeks keanekaragaman Shannon-Wiener dengan rumus : $\mathrm{H}^{\prime}=-\sum_{i-1}^{S} P i \ln P i$

Keterangan : $\quad H^{\prime}=$ Indeks keanekaragaman Shannon

$\mathrm{Pi}=\frac{n i}{N}$ (proporsi jenis ke $-\mathrm{i}$ )

$\mathrm{ni}=$ Jumlah individu jenis ke- $\mathrm{i}$

$\mathrm{N}=$ Jumlah total individu seluruh jenis

Kriteria yang digunakan untuk menginterpretasikan keanekaragaman Shannon-Wiener dalam Bengen (2000), yaitu:

$\mathrm{H}^{\prime}=<1$, keanekaragaman rendah

$\mathrm{H}^{\prime}=1-3$, keanekaragaman tergolong sedang

$\mathrm{H}^{\prime}=>3$, keanekaragaman tergolong tinggi.

Untuk mengetahui seberapa besar kesamaan penyebaran jumlah individu tiap jenis Gastropoda digunakan indeks keseragaman, yaitu dengan cara membandingkan indeks keanekaragaman dengan nilai maksimumnya, dengan rumus :

$$
\mathrm{E}=\frac{\mathrm{H}^{\prime}}{\text { Hmaks }}
$$

Keterangan : $\stackrel{\mathrm{Emaks}}{\mathrm{E}}=$ Indeks keseragaman

$$
H^{\prime}=\text { Indeks keanekaragaman }
$$

H'maks = Indeks keanekaragaman maksimum

$$
=\ln \mathrm{S}(\text { dimana } \mathrm{S}=\text { jumlah jenis })
$$

Indeks keseragaman berkisar antara $0-1$. Bila indeks keseragaman kurang dari 0,4 maka ekosistem tersebut berada dalam kondisi tertekan dan mempunyai keseragaman rendah. Jika indeks keseragaman antara 0,4 sampai 0,6 maka ekosistem tersebut pada kondisi kurang stabil dan mempunyai keseragaman sedang. Jika indeks keseragaman lebih dari 0,6 maka ekosistem tersebut dalam kondisi stabil dan mempunyai keseragaman tinggi.

Untuk menggambarkan jenis Gastropoda yang paling banyak ditemukan, dapat diketahui dengan menghitung nilai dominasinya. Dominasi dapat dinyatakan dalam indeks dominasi Simpson (Brower, 1989) :

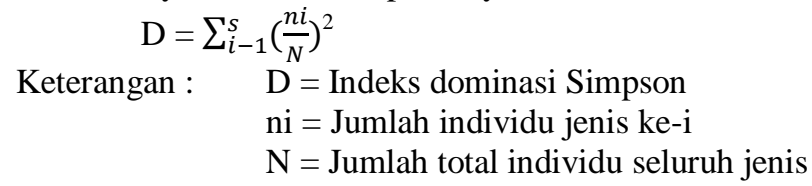

Nilai indeks dominansi berkisar antara $0-1$. Semakin besar nilai indeks semakin besar kecenderungan salah satu spesies yang mendominasi populasi. 


\section{Hasil dan Pembahasan}

\section{Karakteristik Kimia dan Fisika Perairan}

Lokasi pengamatan penelitian ini dilakukan pada 3 titik, yaitu sebelah utara, sebelah timur, dan sebelah selatan Pulau Pramuka. Pada titik sebelah utara Pulau Pramuka merupakan Stasiun 1 yang terdapat makroalga Sargassum sp, Euchema sp, Halimeda sp, Padina sp dan Caulerpa sp, sebelah timur Stasiun 2 dengan makroalga yang mendominasi Halimeda sp, Padina sp dan Caulerpa sp, sedangkan sebelah selatan Stasiun 3 dengan makroalga Euchema sp, Halimeda sp, dan Padina sp. Hasil pengukuran parameter fisika kimia perairan yang dapat dilihat pada tabel 1 .

Tabel 1. Karakteristik Fisika dan Kimia Perairan Pulau Pramuka

\begin{tabular}{clccc}
\hline No. & \multicolumn{1}{c}{ Parameter } & Stasiun 1 & Stasiun 2 & Stasiun 3 \\
\hline & A. Fisika & & & \\
1. & Suhu Perairan $\left({ }^{\circ} \mathrm{C}\right)$ & 30 & 30 & 32 \\
2. & Kecepatan Arus $(\mathrm{m} / \mathrm{s})$ & 0,077 & 0,10 & 0,027 \\
3. & Kecerahan $(\mathrm{cm})$ & $\sim$ & $\sim$ & $\sim$ \\
4. & Kedalaman $(\mathrm{cm})$ & 100 & 95 & 100 \\
& B. Kimia & & & \\
1. & Salinitas $(\%)$ & 33 & 31 & 31 \\
2. & pH & 8 & 6 & 7 \\
\hline
\end{tabular}

Suhu perairan pada Pulau Pramuka mempunyai kisaran antara $30-32{ }^{\circ} \mathrm{C}$. Suhu tertinggi pada stasiun 3 yaitu $32{ }^{\circ} \mathrm{C}$, sedangkan suhu terendah terdapat pada stasiun 1 dan 2 yaitu $30{ }^{\circ} \mathrm{C}$. Pada stasiun 3 suhu air merupakan yang tertinggi diantara yang lain dikarenakan pada saat mengukur suhu air dilakukan tepat pada siang hari pukul $13.00 \mathrm{WIB}$.

Kecepatan arus yang terukur berkisar antara $0,027-0,10 \mathrm{~m} / \mathrm{s}$. Arus ini terbilang cukup tenang. Kecepatan arus pada Stasiun 3 relatif lebih rendah dari stasiun lainnya. Selain itu, kecerahan perairan di lokasi penelitian yaitu tak hingga ( ), dikarenakan pada saat sampling pada siang hari dan dasar perairan masih terlihat dan cuacanya pun cerah.

Kedalaman perairan di daerah pengamatan berkisar antara $95-100 \mathrm{~cm}$, yang dimana pengambilan contoh dilakukan sampai \pm 100 meter dari pinggir pantai. Ini menandakan topografi pantai di pulau ini yang landai. Kedalaman perairan diukur pada saat perairan dalam keadaan surut yang bertujuan agar perhitungan dan pengamatan untuk Lambis mudah dilakukan.

Nilai salinitas di Pulau Pramuka berkisar antara $31-33 \%$. Salinitas terendah terdapat pada Stasiun 2 dan 3, yaitu $31 \%$. Pantai di daerah ini ditumbuhi oleh vegetasi mangrove dengan kepadatan sedang. Salinitas tertinggi terdapat pada Stasiun 1 yaitu $33 \%$.

Kisaran nilai derajat keasaman $(\mathrm{pH})$ di lokasi pengamatan antara 6 - 8. Derajat keasaman tertinggi di Stasiun 1 dengan $\mathrm{pH} 8$ dan $\mathrm{pH}$ terendah di Stasiun 2 dengan $\mathrm{pH} 6$ dikarenakan pada saat sampling cuaca mendung dan sempat hujan. Nilai tersebut memperlihatkan bahwa $\mathrm{pH}$ perairan bersifat basa, asam dan termasuk normal untuk $\mathrm{pH}$ air laut di Indonesia.

\section{Tekstur Substrat Perairan}

Tipe substrat dari ketiga stasiun yang didapatkan pada setiap stasiun di Pulau Pramuka tersaji dalam Tabel 2.

Tabel 2. Tekstur Substrat (\%)

\begin{tabular}{ccccc}
\hline Stasiun & Gravel (kerikil) & Pasir & Silt (lanau) & Tipe Substrat \\
\hline 1 & 69,40 & 30,58 & 0,02 & Gravel (kerikil) \\
2 & 32,97 & 63,73 & 3,30 & Pasir \\
3 & 38,43 & 51,16 & 10,41 & Pasir \\
\hline
\end{tabular}

\section{Kelimpahan Gastropoda (Lambis spp.)}

Gastropoda yang didapatkan di Pulau Pramuka selama penelitian seluruhnya ada 21 individu yang terdiri dari 4 (empat) spesies dari genus Lambis, famili Strombidae dan ordo Mesogastropoda.

(Tabel 3)

Adapun spesies gastropoda yang didapatkan pada semua stasiun 1,2, 3 yaitu masing-masing 4, 2, dan 3 spesies

Tabel 3. Kelimpahan Spesies Lambis Pada Pengamatan Kuadran (1 x $1 \mathrm{~m})$

\begin{tabular}{llcccc}
\hline No. & Spesies Lambis & Stasiun $\mathbf{1}$ & Stasiun 2 & Stasiun 3 & Total \\
\hline 1. & Lambis crocata & 5 & 1 & 5 & 11 \\
2. & Lambis lambis & 3 & 1 & 2 & 6 \\
3. & Lambis chiragra & 1 & - & - & 1 \\
4. & Lambis scorpius & 2 & - & 1 & 3 \\
\hline
\end{tabular}

Tabel diatas menujukkan bahwa spesies gastropoda (Lambis spp.) didapatkan paling banyak di stasiun 1 yaitu 4 spesies. Hal ini sangat dipengaruhi salah satunya oleh kondisi perairan yang relatif tenang karena berada sisi utara 
Pulau Pramuka yang terlindung dari laut lepas. Tercatat pada stasiun 1 rata-rata kecepatan arus adalah 0,077 m/s. Kecepatan arus tersebut tergolong sangat lambat. Kecepatan arus pada stasiun 3 tidak berbeda jauh dengan stasiun 1, sehingga kondisi ini menunjang berbagai jenis gastropoda untuk hidup dan berkembang biak. Selain itu, dengan kondisi perairan seperti ini sangat menunjang perkembangbiakan makroalga yang merupakan ekosistem tempat di mana gastropoda dapat hidup dan berkembang biak.

Sementara itu, pada stasiun 2 ditemukan hanya 2 spesies gastropoda Lambis dan merupakan stasiun dengan jumlah spesies gastropoda yang paling rendah. Kondisi perairan dengan kecepatan arus dan tingkat kedalaman yang tergolong tinggi dibanding dengan stasiun-stasiun lainnya mengindikasikan agak sulit gastropoda berkembang biak. Kecepatan arus pada stasiun ini rata-rata $0,1 \mathrm{~m} / \mathrm{s}$, kendati tergolong masuk dalam arus lambat, namun nilai tersebut paling tinggi jika dibandingkan dengan stasiun lainnya.

Spesies-spesies Lambis yang ditemukan pada saat penelitian yaitu Lambis crocata, Lambis lambis, Lambis scorpius, dan Lambis chiragra. Kelimpahan spesies Lambis berdasarkan kepadatan per plot (1x1 m) yang ditemukan pada Stasiun 1, 2 dan 3 tersaji pada Gambar 1.

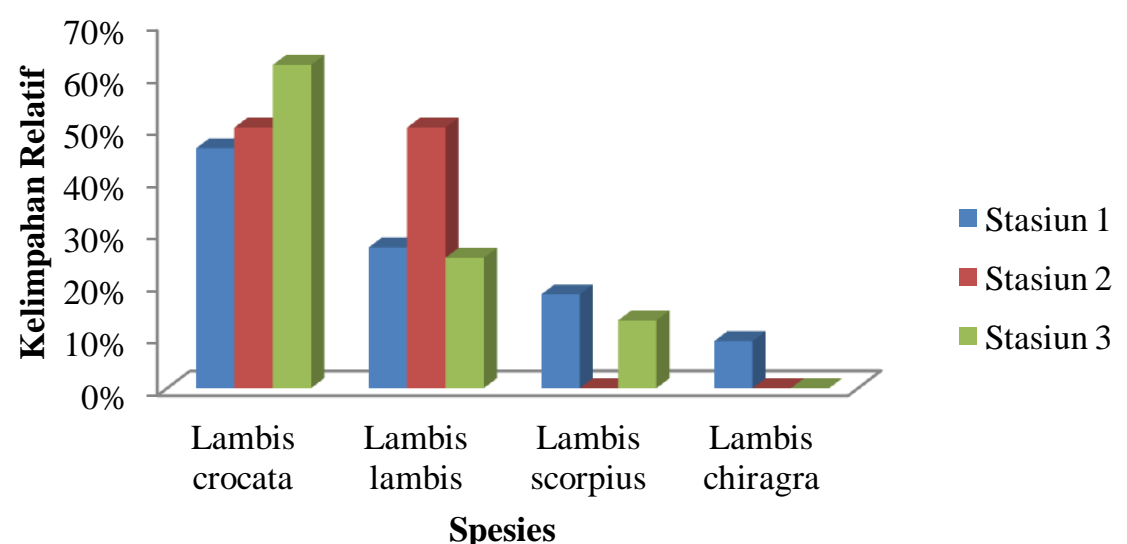

Gambar 1. Diagram Batang Kelimpahan Spesies Lambis setiap Stasiun

Pola kepadatan Lambis didapat hasil yang berbeda setiap stasiun. Berdasar gambar diatas, secara umum Lambis di Pulau Pramuka didominasi oleh Lambis crocata. Lambis jenis Lambis crocata menunjukkan bahwa jenis ini ditemui di semua stasiun pengambilan contoh. Ini menunjukkan bahwa Lambis crocata mampu beradaptasi dengan baik di perairan Pulau Pramuka. Komposisi spesies Lambis secara keseluruhan berdasarkan semua stasiun di Pulau Pramuka dapat dilihat pada Gambar 2.

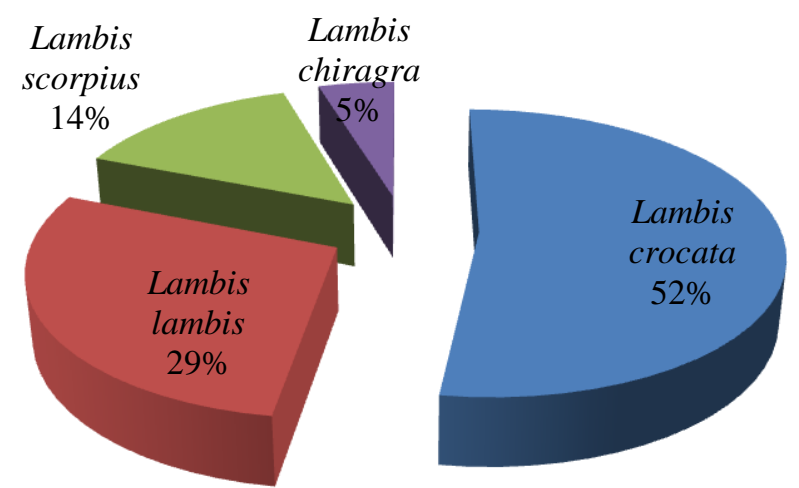

Gambar 2. Komposisi Lambis di Pulau Pramuka

Komposisi tersebut menunjukkan Lambis chiragra yang paling rendah didapatkan di Pulau Pramuka yaitu sebesar $5 \%$. Kemudian ada Lambis scorpius sebesar $14 \%$ dan Lambis lambis dengan komposisi sebanyak 29 \%. Komposisi jenis paling tinggi dicapai oleh Lambis crocata sebanyak $52 \%$. Perbedaan yang cukup jauh komposisi antara Lambis crocata dengan Lambis chiragra, dikarenakan Lambis chiragra rata-rata banyak ditemukan di kedalaman > 1 meter.

\section{Indeks Keanekaragaman (H'), Keseragaman (E) dan Dominasi (D) Gastropoda (Lambis spp.)}

Indeks keanekaragaman (H') populasi Lambis pada perairan Pulau Pramuka berkisar antara 0,69 - 1,24.

Kisaran nilai tersebut menggambarkan bahwa populasi Lambis di Pulau Pramuka dapat dikategorikan memiliki keanekaragaman yang rendah sampai sedang. Keanekaragaman yang paling rendah terdapat pada Stasiun 2 dengan 
kategori rendah dan keanekaragaman tertinggi pada Stasiun 1 dengan kategori sedang. Jenis Lambis yang ditemukan di Stasiun 1 lebih banyak jika dibanding dengan jenis Lambis yang ditemukan di Stasiun 2 dan 3. Namun, jenis Lambis yang ditemukan hanya empat spesies atau hanya berbeda sedikit dengan kondisi ekologi Stasiun 2 dan 3. Nilai Indeks Keanekaragaman (H'), Keseragaman (E) dan Dominasi (D) Gastopoda (Lambis) tersaji pada Tabel 4 berikut.

Tabel 4. Indeks Keanekaragaman (H'), Keseragaman (E) dan Dominansi (D) Gastropoda (Lambis spp.)

\begin{tabular}{ccccc}
\hline No. & Stasiun & H' & E & D \\
\hline 1. & 1 & 1,24 & 0,89 & 0,315 \\
2. & 2 & 0,69 & 1 & 0,50 \\
3. & 3 & 0,89 & 0,82 & 0,473 \\
\hline
\end{tabular}

Nilai keseragaman (E) berkisar antara 0,82 - 1. Nilai tertinggi terdapat pada Stasiun 2 dengan kategori keseragaman tinggi dan nilai terendah pada Stasiun 3 dengan kategori keseragaman juga tinggi, ini berarti bahwa populasi Lambis pada Pulau Pramuka dalam keadaan stabil. Nilai dominasi (D) Lambis pada perairan Pulau Pramuka berkisar antara $0,315-0,50$. Nilai dominasi berkisar antara $0-1$. Nilai yang terbesar terdapat pada Stasiun 2 , dimana pada stasiun ini hanya ada dua spesies yaitu Lambis crocata dan Lambis lambis yang masing-masing mendominasi dengan jumlah yang sama pula. Nilai terkecil terdapat pada Stasiun 3. Semakin besar nilai indeks, maka semakin besar adanya kecenderungan salah satu spesies yang mendominasi populasi.

\section{Jenis-jenis Makroalga yang ditemukan di Pulau Pramuka}

Jenis-jenis makroalga yang ditemukan dan berasosiasi dengan Gastropoda (Lambis spp.) saat sampling di tiga titik (stasiun) di Pulau Pramuka secara umum termasuk dalam tiga divisi yaitu Clorophyta (alga hijau), Phaeophyta (alga coklat), dan Rhodophyta (alga merah). Ciri-ciri yang diamati dari ciri morfologi yang diperoleh dari lokasi penelitian dan dipadukan dengan ciri-ciri yang tercantum pada literatur. Hasil identifikasi berdasarkan ciri-ciri dari masing-masing makroalga yang ditemukan adalah spesies Sargassum sp, Halimeda sp, Padina sp, Caulerpa sp dan Euchema sp. Dan juga ada sebagian kecil jenis lamun berada disekitar makroalga dan Gastropoda (Lambis spp.) yaitu jenis Enhalus sp, Thalassia sp, dan Cymodocea rotundata.

\section{Faktor Lingkungan}

\section{a. Karakteristik Substrat}

Tipe substrat pada Pulau Pramuka sebagian besar terdiri dari pasir. Secara umum seluruh stasiun mempunyai komposisi pasir jauh lebih besar, yaitu sekitar 30,58 \% - 63,73\% dibandingkan dengan komposisi gravel (kerikil) dan silt (lanau). Tipe substrat pada masing-masing titik atau stasiun berbeda-beda. Mulai dari titik utara atau Stasiun 1, gravel (kerikil) sebanyak 69,40 \%, pasir sebanyak 30,58 \% dan silt (lanau) sebanyak 0,02 \%. Pada Stasiun 1 ini yang lebih dominan adalah gravel (kerikil) dibandingkan pasir. Pada titik timur atau Stasiun 2 didapatkan gravel (kerikil) sebanyak 32,97\%, pasir sebanyak 63,73\% dan silt (lanau) sebanyak 3,30\%. Dan yang terakhir pada titik selatan atau Stasiun 3 Pulau Pramuka adalah gravel (kerikil) sebanyak 38,43\%, pasir sebanyak 51,16 \%, dan silt (lanau) sebanyak 10,41 \%. Pada Stasiun 2 dan 3 Pulau Pramuka lebih didominasi oleh pasir jika dibandingkan dengan gravel (kerikil) dan silt (lanau). Gastropoda (Lambis spp.) umumnya hidup diantara karang-karang, di pantai-pantai yang dasarnya terdiri dari pecahan-pecahan karang atau pasir. Sehingga gastropoda (Lambis spp.) lebih menyukai substrat yang berupa pasir dan gravel atau batu kerikil/pecahan-pecahan karang.

\section{b. Salinitas}

Salinitas yang terukur berkisar antara 31 - $33 \%$. Nilai salinitas yang didapatkan dari pengukuran ini belum dapat menjadi faktor pembatas melimpahnya gastropoda (Lambis spp.). Menurut Pennak (1978) salinitas optimum bagi gastropoda berkisar antara 26 - 32 \%. Hal ini menunjukkan bahwa kisaran salinitas yang didapat dari penelitian ini masih dalam kisaran nilai toleransi hewan gastropoda.

\section{c. $\mathbf{p H}$}

Hasil pengukuran nilai $\mathrm{pH}$ di titik utara adalah 8 , nilai $\mathrm{pH}$ di titik timur adalah 6. Sedangkan pada titik selatan bernilai 7. Perbedaan rata-rata nilai $\mathrm{pH}$ antara ketiga titik tersebut berkisar $1-2$. Besarnya nilai $\mathrm{pH}$ di perairan ini relatif sedang untuk nilai $\mathrm{pH}$ air laut, akan tetapi masih memungkinkan biota laut untuk bertahan hidup. Umumnya $\mathrm{pH}$ air laut relatif stabil dengan kisaran antara 7,5 - 8,4. Pescod dalam Susana (2005) memberikan batasan pH yang ideal bagi biota laut nilainya berkisar antara $6,5-8,5$.

\section{d. Kecepatan Arus}

Kecepatan arus tersebut tergolong sangat lambat seperti yang dikemukakan oleh Mason (1981) dalam Mariska (2007) yang mengelompokkan perairan berarus sangat cepat (>1m/dtk), cepat $(0,5-1 \mathrm{~m} / \mathrm{dtk})$, sedang $(0,25-0,5 \mathrm{~m} / \mathrm{dtk})$, lambat $(0,1-0,2 \mathrm{~m} / \mathrm{dtk})$ dan sangat lambat $(<0,1 \mathrm{~m} / \mathrm{dtk})$. Sebagaimana yang dikemukakan oleh Supriharyono (2000) bahwa arus sangat mempengaruhi sebaran atau perpindahan dari organisme hewan bentos termasuk gastropoda bahwa arus dapat membawa organisme bentos dari suatu tempat ke tempat lain di perairan.

\section{e. Suhu}


Perbedaan suhu terjadi dapat dimungkinkan karena waktu pengukuran suhu yang berbeda. Suhu perairan di Pulau Pramuka masih tergolong normal dan cocok untuk syarat hidup dari bivalvia dan gastropoda. Seperti yang dikemukakan oleh Krebs (1989) bahwa perkembangan normal bivalvia dan gastropoda pada kisaran suhu antara 18 - 30 ${ }^{0} \mathrm{C}$, sedangkan suhu untuk pertumbuhan optimum adalah $24-30{ }^{0} \mathrm{C}$ dimana suhu tersebut berpengaruh terhadap metabolisme tubuh. Hal tersebut diperkuat oleh pendapat Hutabarat dan Evans (1995) yang menyatakan bahwa suhu diperairan merupakan salah satu faktor penting bagi kehidupan organisme didalamnya, karena suhu mempengaruhi aktivitas metabolisme maupun perkembangbiakkan. Secara ekologis perubahan suhu menyebabkan perbedaan komposisi dan kelimpahan bivalvia dan gastropoda. Sedangkan Krebs (1989) berpendapat bahwa suhu mempengaruhi daur hidup organisme dan merupakan faktor pembatas penyebaran suatu jenis dalam hal mempertahankan kelangsungan hidup, reproduksi, perkembangan, dan kompetisi.

\section{Asosiasi Makroalga dengan Gastropoda (Lambis spp.)}

Interaksi yang terjadi antara makroalga dan hewan gastropoda berlangsung positif dimana interaksi terjadi adalah protokooperasi, yaitu bentuk asosiasi dimana kedua belah pihak mengalami keuntungan, tetapi tidak terjadi faktor ketergantungan. Gastropoda memanfaatkan makroalga sebagai salah satu sumber makanannya serta sebagai tempat berlindung. Bagi makroalga, gastropoda sangat penting terutama dalam siklus nutrien, yaitu secara tidak langsung menghasilkan mineral-mineral yang dibutuhkan dalam fotosintesis dan berperan dalam perkembangbiakannya dengan membantu penyebaran spora makroalga (Leitte dan Turra, 2003).

Nogueira (2003) mengemukakan adanya keterkaitan antara makroalga dengan keberadaan gastropoda. Menurut Hayes (2007), di daerah pasang surut distribusi makroalga berkaitan erat dengan keberadaan gastropoda. Kelimpahan organisme pada suatu komunitas dipengaruhi oleh faktor ekologinya. Menurut Tumer et al., (1999) menyebutkan bahwa suatu habitat tidak dapat berdiri sendiri sedangkan Branco et al., (2001) mengemukakan bahwa distribusi alga banyak dipengaruhi oleh berbagai faktor fisika kimia seperti kandungan nitrat fosfat, kecerahan, $\mathrm{pH}$, dan kandungan oksigen.

\section{Kesimpulan dan Saran}

Kesimpulan yang diperoleh berdasarkan hasil penelitian ini adalah Jenis-jenis Lambis spp. yang ditemukan saat penelitian yaitu Lambis crocata, Lambis lambis, Lambis scorpius, dan Lambis chiragra dengan komposisi Lambis crocata $52 \%$, Lambis lambis $29 \%$, Lambis scorpius $14 \%$ dan yang paling rendah yaitu Lambis chiragra dengan $5 \%$. Kelimpahan Lambis yang didapatkan di Pulau Pramuka selama penelitian seluruhnya ada 21 individu, dengan jumlah total pada Stasiun 1 yaitu 11 individu, pada Stasiun 2 dengan jumlah 2 individu dan Stasiun yang ke 3 dengan jumlah 8 individu dan Jenis-jenis makroalga yang ditemukan adalah spesies Sargassum sp, Halimeda sp, Padina sp, Caulerpa sp dan Euchema sp. Saran yang dapat disampaikan penulis pada penelitian adalah Untuk kesempurnaan penelitian ini perlu dilakukan penelitian lanjutan.

\section{Ucapan Terimakasih}

Pada kesempatan ini penulis mengucapkan terimakasih kepada Ir. Siti Rudiyanti M.Si dan Dr. Ir. Max Rudolf Muskananfola M.Sc yang telah membantu dalam penyusunan penulisan ini, serta Bapak Zakariya atas bantuan dalam membimbing dilapangan saat sampling.

\section{Daftar Pustaka}

Branco, L.H.Z., Orlando N.J. and Ciro Caesar Z.B. 2001. Ecological Distribusi of Cyanophyceae in Lotic Ecosystems of Sao Paulo State. Revta Brasil Botanica 24 (1): 99-108.

Departemen Kehutanan. 2005. Pengenalan Jenis Biota Laut Moluska. PT Sakarindo Mekar Abadi. Bogor.

Gulo, W. 2005. Metodologi Penelitian. Grasindo. Jakarta.

Hayes, C. 2007. Vertical Distribution of Algal Species in Rock Pools in South-Eastern Australia. Cross Sections 3: 3349.

Hutabarat, S dan Evans, S.M. 1995. Pengantar Oseanografi. Universitas Indonesia Press. Jakarta. 123-124 pp.

Kasenda, P. 2012. Sea Marine Education Siput Gastropoda yang Menempel pada Alga Makro. http://petroskasenda.blogspot.com/2012/03/siput-gastropoda yang-menempel-pada.html.

Kastoro, W. 1982. Shallow Water Marine Molluscs of North-West Java. Lembaga Oseanologi Nasional, Lembaga Ilmu Pengetahuan Indonesia. Jakarta.

Krebs, CJ. 1989. Ecology The Experimental Analysis of Distribution and Abundance $3^{\text {nd }}$ edition. Harper and Row Publisers. New York. 776 pp. 
Leitte, F.P.P. and Turra, A. 2003. Temporal Variation in Sargassum Biomass, Hypnea Epiphytism and Associated Fauna. Brazilian Arch Biol and Technol. 46 (4): 665-671.

Mariska, I. 2007. Penentuan Pola Sebaran Makrozoobentos Berdasarkan Kedalaman Di Perairan Teluk Labuange, Kabupaten Barru. (Skripsi) Ilmu Kelautan. FIKP-Unhas. Makassar.

Nogueira, J.M.D.M. 2003. Fauna Living in Collonies of Mussismilia hispida (Verrill) (Cnidaria Scleractinia) in Four South-Eastern Brazil Islands. Brazilian Arch. Biol and Technol. 46 (3): 421-432.

Pennak, R.W. 1978. Freswater Invertebrates of the United States. Second ed. A Willey Interscience Publication. Jhon Willey and Sons, Inc. New York.

Susana, T. 2005. Kualitas Zat Hara Perairan Teluk Lada. Oseanologi dan Limnologi di Indonesia : 59- 67. Banten.

Tumer, S.J., S.F. Thrush, J.E. Hewitt, V.J. Cummings and G. Funnell. 1999. Fishing Impacts and The Degradation or Loss of Habitat Structure. Fish Manag Ecol. 6: 401-420. 